\title{
Anna Pluszyńska
}

\author{
Uniwersytet Jagielloński
}

\section{KODEKSY ETYKI A REgULACJE PRAWNE}

\begin{abstract}
Code of ethics and legal regulations. Code of ethics defines the main values and principles that regulate the activities of different types of organizations in the advertising industry. There are few organizations involved in raising ethical standards in Poland and forming the rules of ethical standards in Polish advertising. Anyhow the author will focus on the example of the Advertising Ethics Code, promoted by the Union of Associations Advertising Council. While analyzing the Code, it is not difficult to notice that it largely reproduce the contents of the legal regulations. That is why author will try to answer the following questions: Are the regulations contained in the Code value added for interpretation of the law and whether the formulation of ethical standards in Polish advertising is justified?

Kodeksy etyki a regulacje prawne. Kodeksy etyki określają koronne wartości i zasady, które regulują działalność różnych organizacji z branży reklamowej. Jest kilka organizacji zaangażowanych w podnoszenie standardów etycznych w Polsce, tworzących m.in. zasady norm etycznych w polskiej reklamie, ale autorka skoncentruje się na przykładzie Kodeksu Etyki Reklamy, promowanego przez Związek Stowarzyszeń Rada Reklamy. Analizując sformułowania zawarte w tym kodeksie, nietrudno zauważyć, że stanowią one w dużej mierze powtórzenie treści ustaw, dlatego autorka postara się odpowiedzieć na następujące pytania: Czy regulacje prawne zawarte $\mathrm{w}$ kodeksie stanowią dodatkową wartość $\mathrm{w}$ interpretacji przepisów prawa i czy formułowanie norm etycznych w polskiej reklamie ma, prócz wartości wizerunkowej, uzasadnienie?
\end{abstract}

Keywords law, ethics, code of ethics, advertising, self-regulation

prawo, etyka, kodeks etyki, reklama, samoregulacja 


\section{Prawo i etyka W ZAKRESie ReKLAMY}

Termin „reklama” wywodzi się od łacińskich słów reclamo, reclamare, reclamavi, reclamatum, które oznaczają głośne wołanie, nawoływanie, krzyczenie, głośne sprzeciwianie się, hałasowanie, robienie wrzawy. Choć na podstawie etymologii słowa można by sądzić, że reklama istnieje bardzo długo ${ }^{1}$, to jednak sposób jej tworzenia i postrzegania ulegał bezustannej zmianie.

W Kodeksie Etyki Reklamy propagowanym przez Związek Stowarzyszeń Rada Reklamy stwierdzono, że reklamą jest „przekaz zawierający w szczególności informacje lub wypowiedzi, zwłaszcza odpłatny lub za wynagrodzeniem w innej formie, towarzyszący czyjejkolwiek działalności, mający na celu zwiększenie zbytu produktów, inną formą korzystania $\mathrm{z}$ nich lub osiągnięcie innego efektu, które są pożądane przez reklamodawcę" ${ }^{2}$. Obecnie jest sposobem wywierania wpływu na nabywców, informowania ich o produktach/usługach i zachęcania do ich zakupu. Staje się dźwignią handlu, narzędziem walki konkurencyjnej i podstawą sukcesu rynkowego wielu przedsiębiorstw. W szerszym ujęciu reklama jest nie tylko formą aktywizacji sprzedaży, ale także częścią bardziej obszernego zestawu działań i instrumentów, zwanego marketingiem. Nieco upraszczając, marketing polega na poznaniu potrzeb potencjalnych nabywców oraz dostarczeniu produktu dostosowanego do ich oczekiwań, w dodatku po właściwej cenie, we właściwym miejscu i czasie oraz przy użyciu właściwej formy promocji ${ }^{3}$.

Kolejne pojęcia, fundamentalne dla niniejszego tekstu, to „prawo” i „etyka”. Obydwa terminy definiowane są w literaturze przedmiotu bardzo szeroko. Przykładowo Słownik współczesnego języka polskiego uważa prawo za „przyjęty przez ogół społeczeństwa system reguł, norm wyznaczających to, co dozwolone, i co zakazane, który określa także kary za wykroczenia, spowodowane złamaniem owych reguł" 4 . Ten sam słownik termin „etyka” wyjaśnia jako „system wartości i norm postępowania. Obowiązujący w danej zbiorowości lub w danej epoce" 5 .

Robert Grochowski zauważa, że „problem oceny reklamy pod względem moralności i prawa należy do najbardziej dyskusyjnych. Granice, poza którymi kończy się sztuka, informacja i prawda, a zaczyna manipulacja i fałsz, są w reklamie bardzo zatarte" ${ }^{\text {. }}$ Z pewnością głównym „celem reklamy nie jest prawdziwie odwzorowywać świat realny, ale przede wszystkim przyciągać uwagę, «sprawiać wrażenie», zadziwiać, dostarczać przyjemności. Dlatego uprawnione i pożądane w reklamie jest operowanie kreacją, przesadą, nieokreślonością, subiektywnością"7. Wielce nieuzasadnione byłoby jednak traktowanie reklam wyłącznie jako działania manipulacyjnego. Ale ponieważ zauważalne

${ }^{1}$ K. Janiszewska i in., Wiedza o reklamie. Od pomystu do efektu, Bielsko-Biała 2010, s. 103.

2 Źródło: https://www.radareklamy.pl/kodeks-etyki-reklamy?showall=\&start=2 (08.09.2017).

3 R. Nowacki, Podręcznik. Reklama, Warszawa 2006, s. 12-13.

${ }^{4}$ Słownik współczesnego słownika polskiego, red. B. Dunaj, Warszawa 1996, s. 848.

5 Słownik współczesnego słownika polskiego, dz. cyt., s. 242.

6 R. Grochowski, Granice prawne i etyczne reklamy w ustawodawstwie krajowym i europejskim, PoznańOpole 2010, s. 13.

${ }^{7}$ K. Janiszewska i in., Wiedza o reklamie..., dz. cyt., s. 108. 
są zagrożenia, działalność reklamowa podlega regulacjom prawnym i dobrowolnym obostrzeniom (formułowanym w treści kodeksów etyki reklamowej).

Obecnie w Polsce możemy wyróżnić trzy systemy regulujące działalność reklamową :

- sądowy - dotyczący zasad objętych w odrębne ustawy lub orzeczenia sądów (przykład: ustawa o zwalczaniu nieuczciwej konkurencji ${ }^{9}$ );

- administracyjny - polegający na stanowieniu i sprawowaniu kontroli przestrzegania przepisów administracyjnych przez specjalnie powołane do tego instytucje państwowe (np. KRRiT sprawuje typowe funkcje dla organu administracji publicznej, m.in. wydając koncesję w formie decyzji administracyjnej);

- samokontroli - polegający na ustanawianiu i dobrowolnym przyjmowaniu ograniczeń przez środowisko reklamowe.

W prawie polskim regulacji dotyczących reklamy jest wiele. Wśród najważniejszych przepisów, które normują działalność reklamową, należy wyróżnić te, które ${ }^{10}$ :

- zakazują nieuczciwej reklamy (ustawa z dnia 16 kwietnia 1993 r. o zwalczaniu nieuczciwej konkurencji oraz ustawa $z$ dnia 23 sierpnia 2007 r. o przeciwdziałaniu nieuczciwym praktykom rynkowym);

- zakazują lub normują reklamowanie określonych grup produktów i usług (np. ustawa z dnia 26 października 1982 r. o wychowaniu w trzeźwości i przeciwdziałaniu alkoholizmowi; ustawa z dnia 9 listopada 1995 r. o ochronie zdrowia przed następstwami używania tytoniu i wyrobów tytoniowych; ustawa z dnia 26 lipca 2005 r. o przeciwdziałaniu narkomanii; ustawa z dnia 19 listopada 2009 r. o grach hazardowych; ustawa z dnia 6 września 2001 r. Prawo farmaceutyczne);

- regulują działalność reklamową w środkach masowego przekazu (ustawa z dnia 26 stycznia 1984 r. Prawo prasowe; ustawa z dnia 29 grudnia 1992 r. o radiofonii i telewizji) oraz

- chronią wybrane elementy reklamy (ustawa z dnia 4 lutego 1994 r. o prawie autorskim i prawach pokrewnych; ustawa z dnia 30 czerwca 2000 r. Prawo własności przemysłowej).

Aktów prawnych regulujących działalność reklamową jest wiele, ale w literaturze przedmiotu podkreśla się, że nadal pozostawiają one wiele wątpliwości i niejasności ${ }^{11}$. Dlatego środowiska związane $\mathrm{z}$ reklamą tworzą własne mechanizmy samoregulacji. Najczęściej dobrowolnie podejmują się przestrzegania kodeksów etyki reklamy, których celem jest niedopuszczenie do występowania nieuczciwych praktyk rynkowych i nagannych zachowań obniżających standardy przekazu reklamowego oraz rozstrzyganie sporów we własnym zakresie. Robert Nowacki etykę reklamy definiuje jako „zespół norm moralnych i zasad postępowania przyjętych w branży reklamowej odnoszących

${ }^{8}$ J. Ciechanowski, Etyczne granice reklamy politycznej, „Zeszyty naukowe Uniwersytetu Rzeszowskiego” 77 (2013), s. 24.

9 Ustawa z dnia 16 kwietnia 1993 r. o zwalczaniu nieuczciwej konkurencji, Dz.U. 1993 Nr 47 poz. 211 ze zm.

10 A. Pluszyńska, Prawo reklamy, w: Zarządzanie reklamą, red. B. Nierenberg, Kraków 2015, s. 57-80.

11 K. Grzybczyk, Prawo reklamy, Warszawa 2008, s. 206; R. Nowacki, Podręcznik. Reklama, dz. cyt., s. 230; A. Karpowicz, Jak reklamować się zgodnie z prawem, Warszawa 1997, s. 56. 
się do relacji pomiędzy firmą a jej klientami, partnerami handlowymi, pracownikami oraz konkurentami"12.

Wśród kodeksów etyki reklamy wymienić można ${ }^{13}$ :

- Kodeks Etyki Reklamy (pierwsza wersja została podpisana w 2004 roku, od tamtej pory kilkukrotnie zmieniany) - sformułowany przez członków Związku Stowarzyszeń Rada Reklamy. Jest to kodeks etyki działalności marketingowej, reklamowej, dystrybucyjnej, sponsoringowej oraz promocji sprzedaży; zawiera zbiór zasad etycznych i dobrych obyczajów, stanowiących podstawę do wdrażania idei odpowiedzialnego biznesu;

- Kodeks postępowania w dziedzinie reklamy - przygotowany na podstawie najstarszego kodeksu regulującego działalność reklamową - Międzynarodowego Kodeksu Etyki Reklamy, opracowanego w 1939 roku przez Izbę Handlową w Paryżu. Kodeks ten jest firmowany przez Międzynarodowe Stowarzyszenie Reklamy IAA w Polsce;

- Zasady etyki w reklamie politycznej - opracowane w 1997 roku. Firmuje je Międzynarodowe Stowarzyszenie Reklamy IAA w Polsce;

- Deklaracja Przeciwdziałania Ukrytej Reklamie;

- Kodeks Dobrych Praktyk Członków Stowarzyszenia Agencji Reklamowych (SAR) - przyjęty przez członków tej organizacji;

- Dobrowolny Kodeks Postępowania w Zakresie Reklamy i Promocji Piwa, przyjęty przez polskie browary w 1998 roku;

- Kodeks postępowania w dziedzinie reklamy zewnętrznej.

Już na tym etapie widać, że kodeksów etyki w dziedzinie reklamy jest wiele. Pytanie, skąd tak duża potrzeba tworzenia mechanizmów samokontroli? By na to pytanie odpowiedzieć, autorka dokona porównania regulacji zawartych w przepisach wybranych ustaw oraz w Kodeksie Etyki Reklamy, jako najbardziej reprezentatywnym dokumencie, i spróbuje odpowiedzieć na następujące pytania: czy normy zawarte w kodeksie stanowią dodatkową wartość $w$ interpretacji przepisów prawa i czy formułowanie norm etycznych w polskiej reklamie ma, prócz wartości wizerunkowych, uzasadnienie?

\section{KODEKS ETYKI REKLAMY A PRZEPISY PRAWA}

Poniżej zostanie dokonana krótka analiza porównawcza podobieństw i różnic $\mathrm{w}$ treści Kodeksu Etyki Reklamy oraz przepisów ustaw obowiązujących w Polsce. Ze względu na ograniczenia objętościowe artykułu zostaną zaprezentowane jedynie najbardziej charakterystyczne przykładowe regulacje.

Analizując normy zawarte w Kodeksie Etyki Reklamy, łatwo zauważyć, że spora część regulacji to powtórzenia rozwiązań ustawowych, choć wyrażonych innymi słowami.

\footnotetext{
12 R. Nowacki, Podręcznik. Reklama, dz. cyt., s. 230.

13 E. Murawska-Najmiec, Informacje na temat istniejących $w$ Polsce zasad etycznych $w$ dziedzinie wplywających na zawartość mediów, „Analiza Biura KRRiT” (2006) nr 8, s. 1-72.
} 
Tabela 1. Podobieństwa

\begin{tabular}{l} 
Przepisy prawa \\
\hline Czynem nieuczciwej konkurencji w zakre- \\
sie reklamy jest reklama odwołująca się \\
do uczuć klientów przez wywoływanie lęku, \\
wykorzystywanie przesądów lub łatwo- \\
wierności dzieci (art. 16 ust 1 pkt 3 ustawy \\
o zwalczaniu nieuczciwej konkurencji). \\
\\
Czynem nieuczciwej konkurencji w zakresie \\
reklamy jest reklama wprowadzająca klienta \\
w błąd i mogąca przez to wpłynąć na jego \\
decyzję co do nabycia towaru lub usługi (art. \\
16 ust 1 pkt 2 ustawy o zwalczaniu nieuczci- \\
wej konkurencji). \\
Czynem nieuczciwej konkurencji jest takie \\
oznaczenie towarów lub usług albo jego brak, \\
które może wprowadzić klientów w błąd \\
co do pochodzenia, ilości, jakości, składni- \\
ków, sposobu wykonania, przydatności, moż- \\
liwości zastosowania, naprawy, konserwacji \\
lub innych istotnych cech towarów albo \\
usług, a także zatajenie ryzyka, jakie wiąże \\
się z korzystaniem z nich (Art. 10. 1. ustawy \\
o zwalczaniu nieuczciwej konkurencji).
\end{tabular}

Bez uzasadnionej konieczności, powodowanej np. względami społecznymi i profilaktyką, reklamy nie mogą motywować do zakupu produktu poprzez wykorzystywanie zdarzeń losowych, wywoływanie lęku lub poczucia strachu (art. 6).

Reklama skierowana do dzieci lub młodzieży nie może wprowadzać w błąd poprzez wykorzystywanie ich naturalnej ufności i braku doświadczenia (art. 24).

Reklamy nie mogą wprowadzać w błąd jej odbiorców, w szczególności w odniesieniu do: a) istotnych cech, w tym właściwości, składu, metody, daty produkcji, przydatności, ilości, pochodzenia (w tym geograficznego) reklamowanego produktu; b) wartości produktu i jego rzeczywistej ceny oraz warunków płatności, w szczególności takich jak sprzedaż ratalna, leasing, sprzedaż na kredyt, sprzedaż okazyjna; c) warunków dostawy, wymiany, zwrotu, napraw i konserwacji; d) warunków gwarancji; e) praw własności intelektualnej i przemysłowej, takich jak w szczególności patenty, nazwy, znaki towarowe oraz wzory przemysłowe i modele; f) urzędowych zezwoleń lub atestów, nagród, medali i dyplomów; g) zakresu świadczeń przedsiębiorcy na cele dobroczynne (art. 10).

Umieszczanie w reklamie bezpośredniego wezwania dzieci do nabycia reklamowanych produktów lub do nakłonienia rodziców lub innych osób dorosłych do kupienia im reklamowanych produktów (art. 9 pkt 5 ustawy z dnia 23 sierpnia 2007 r. o przeciwdziałaniu nieuczciwym praktykom rynkowym).

Ogłoszenia i reklamy muszą być oznaczone w sposób nie budzący wątpliwości, iż nie stanowią one materiału redakcyjnego (art. 36 ust 3 ustawy - prawo prasowe).
Reklamy nie mogą zawierać skierowanych do dzieci lub młodzieży: (i) poleceń nakłaniania osób dorosłych do zakupu reklamowanych produktów lub (ii) instrukcji sposobu nakłaniania osób dorosłych do zakupu reklamowanych produktów (art. 29).

Reklamodawca, promujący, pośrednik i środki przekazu, każdy wyłącznie w zakresie swojej działalności dotyczącej reklamy, będzie przestrzegał zasady, aby odbiorca reklamy powstałej lub rozpowszechnianej z jego udziałem mógł zawsze zidentyfikować, że dany przekaz jest reklamą (art. 9). 
Rozpowszechnianie wizerunku wymaga zezwolenia osoby na nim przedstawionej. W braku wyraźnego zastrzeżenia zezwolenie nie jest wymagane, jeżeli osoba ta otrzymała umówioną zapłatę za pozowanie (art. 80 ust. 1 ustawy o prawie autorskim i prawach pokrewnych).
Reklama nie może przedstawiać lub odnosić się do jakiejkolwiek osoby fizycznej, w tym także powszechnie znanej w związku z np. pełnieniem przez nią funkcji publicznych, bez uzyskania jej wcześniejszej zgody, ani też bez uprzedniej zgody opisywać lub odnosić się do rzeczy będącej własnością konkretnej osoby, w sposób mogący wywołać wrażenie jej osobistej rekomendacji (art. 12 ust. 1).
Reklama lub inny rodzaj promocji towaru lub usługi nie powinny zawierać treści propagujących model konsumpcji sprzeczny z zasadami ochrony środowiska i zrównoważonego rozwoju, a w szczególności wykorzystywać obrazu dzikiej przyrody do promowania produktów i usług negatywnie wpływających na środowisko przyrodnicze. Reklama i inny rodzaj promocji, zawierające informację o produkcie w zakresie ochrony środowiska [dodane przez autorkę], powinny być czytelne oraz powinny uwzględniać wymagania określone (art. 80 i 80a ust. 1 ustawy - Prawo ochrony środowiska).

Odbiorcy powinni zostać wyraźnie poinformowani o sponsorowaniu [...]. Wskazanie sponsora może zawierać tylko jego nazwę, firmę, znak towarowy lub inne oznaczenie indywidualizujące przedsiębiorcę lub jego działalność, odniesienie do jego towarów, usług lub ich znaku towarowego (art. 17 ust. 1 ustawy o radiofonii i telewizji).
Reklamy nie mogą naruszać społecznego zaufania do prawidłowo realizowanych działań podejmowanych w zakresie ochrony środowiska naturalnego (art. 33).

Reklamy nie mogą zawierać przekazu, który mógłby wprowadzić konsumentów w błąd w zakresie ochrony środowiska, $w$ tym w szczególności poprzez błędne informowanie o cechach produktów lub co do działań podejmowanych przez reklamodawcę na rzecz ochrony środowiska (art. 35).
Działania związane ze sponsoringiem nie mogą wprowadzać w błąd co do podmiotu, marki lub innych oznaczeń identyfikacyjnych sponsorowanego, w szczególności w sytuacji, gdy sponsorowane wydarzenie jest prezentowane w radiu lub telewizji (art. 43).

Źródło: opracowanie własne.

Kodeks Etyki Reklamy powstał dużo później (pierwsza wersja w 2004 r) niż przywołane ustawy, więc zbytnio nie dziwi, że jego twórcy czerpią z obowiązujących regulacji. Przy tej okazji warto zwrócić uwagę, że w Kodeksie niektóre normy zostały bardziej uszczegółowione, podawane są też liczne przykłady działań niepożądanych lub zalecanych. Tego typu zapisy z pewnością ułatwiają interpretację aktualnych przepisów prawa.

W kodeksie pojawia się także wiele zapisów, które nie zostały wprost zawarte w ustawach regulujących działalność reklamową. Poniżej autorka przedstawia przykładowe zapisy kodeksu: 
Tabela 2. Różnice

Reklama nie może być realizowana w sposób, który naraziłby na uszczerbek obiekty o znaczeniu historycznym lub artystycznym (art. 7).

Reklama nie może nadużywać zaufania odbiorcy, ani też wykorzystywać jego braku doświadczenia lub wiedzy (art. 8).

Reklamy nie mogą propagować postaw kwestionujących prawa zwierząt. Reklamy wykorzystujące wizerunek zwierząt powinna cechować powściągliwość, tak aby zwierzęta nie były przedstawiane w sposób sugerujący możliwość ich niehumanitarnego traktowania (art. 21).

Reklamy skierowane do dzieci lub młodzieży nie mogą zawierać przekazu, że posiadanie lub używanie produktu zapewni im przewagę społeczną lub psychologiczną nad innymi albo nieposiadanie tego produktu odniesie skutek przeciwny (art. 26).

Reklamy zawierające ogólne sformułowanie, w szczególności takie jak „przyjazny środowisku” czy „bezpieczny ekologicznie” nie mogą wprowadzać w błąd. Informacja ze wskazaniem, na czym polega w tym zakresie efekt produktu, musi być dostępna w punkcie sprzedaży lub dołączona do produktu lub będzie udostępniona beneficjentowi w powszechnie dostępny sposób (art. 37).

Źródło: Kodeks Etyki Reklamy, dobór własny.

Środowisko reklamowe, współtworząc treść Kodeksu Etyki Reklamy, zwróciło także uwagę na pewne niepokojące praktyki, które nie zawsze uznane są za bezprawne, a które w opinii reklamodawców, agencji reklamowych, domów mediowych i mediów są nieetyczne. W kodeksie zostały więc wprowadzone dodatkowe ograniczenia dotyczące np. reklam zawierających informacje ekologiczne, reklam piwa, usług bankowych czy żywności skierowanej do dzieci, a także dotyczące sponsoringu, marketingu bezpośredniego czy promocji sprzedaży.

\section{ISTOTA SAMOREGULACJI}

W literaturze przedmiotu podkreśla się, że regulacje prawne dotyczące reklamy są zbyt rozproszone i nastręczają wiele wątpliwości interpretacyjnych. Ustawodawca ponadto często posługuje się pojęciami nieostrymi, co przysparza kolejnych trudności. $\mathrm{Z}$ drugiej strony nie jest możliwe, by zawrzeć $\mathrm{w}$ ustawie szczegółowe reguły postępowania dla każdego rodzaju działalności gospodarczej ${ }^{14}$. „Rolę tę powinny pełnić zasady uczciwego postępowania określone przez poszczególne środowiska" ${ }^{15}$. Sami reklamodawcy zauważyli, że nieuczciwe działania innych mają niekorzystny wpływ na całe środowisko. Chcąc zapobiec nieuczciwej reklamie, otoczenie z nią związane zdecydowało

${ }^{14}$ K. Grzybczyk, Prawo reklamy, dz. cyt., s. 206, A. Karpowicz, Jak reklamować się zgodnie z prawem, dz. cyt., s. 56.

15 A. Karpowicz, Jak reklamować się zgodnie z prawem, dz. cyt., s. 56. 
o stworzeniu własnych mechanizmów samoregulacji, które przyjmowane dobrowolnie, nakładają ograniczenia w zakresie działalności reklamowej ${ }^{16}$.

Kodeks Etyki Reklamy nie ma zastąpić przepisów prawa, a jedynie uzupełniać (ułatwiać interpretację). W samym kodeksie czytamy „że jest to zbiór zasad nakładających na podmioty nim objęte dodatkowe ograniczenia, niezależnie od obowiązujących przepisów prawa" ${ }^{17}$. Powołując się na dokonane w poprzedniej części porównanie treści poszczególnych ustaw i kodeksu, można zauważyć liczne podobieństwa. Wydaje się jednak, że mają one na celu doprecyzowanie klauzul generalnych zawartych w ustawach. Zaletą kodeksu jest z pewnością język, jakim został on napisany. Nie jest on prawniczy, dzięki czemu jest bardziej zrozumiały dla praktyków środowiska reklamowego. Ponadto przywoływane są liczne przykłady, które dodatkowo ułatwiają dokonanie interpretacji nałożonych ograniczeń.

Zalet samoregulacji jest wiele, a wśród nich wymienić można m.in.:

- integrację środowiska w zwalczaniu zjawisk uznanych powszechnie za patologiczne;

- sposób tworzenia - kodeks przygotowywany jest przez zainteresowanych, czyli środowisko reklamodawców, agencji reklamowych i media;

- możliwość powoływania się przez sądy na kodeks, ponieważ reguły zawarte w kodeksie można uznać za uszczegółowienie klauzul generalnych zawartych w ustawach;

- elastyczność - dynamiczna branża bieżąco reaguje na zmieniające się potrzeby i dostosowuje treść kodeksu do tych potrzeb;

- kontrolę przestrzegania zasad, dokonywaną przez środowisko, które zasady stworzyło $^{18}$.

Kodeksy nie są jednak pozbawione wad. Jedną z najważniejszych jest fakt, że o ile ustanowione w kodeksie zasady postępowania skierowane są do szerokiego kręgu podmiotów, tzn. wszystkich organizacji i osób fizycznych związanych z działalnością reklamową (zleceniodawców, twórców reklam, agencji reklamowych i środków przekazu), o tyle do przestrzegania tych norm etycznych są zobowiązani jedynie członkowie Związku Stowarzyszeń Rada Reklamy oraz sygnatariusze mający certyfikat „Reklamuję etycznie”. W stosunku do tych podmiotów można wyciągnąć sankcje organizacyjne i co ważne, zgodnie z regulaminem, takiemu podmiotowi może zostać odebrany certyfikat lub/i może on zostać pozbawiony członkostwa w stowarzyszeniu. Warto przy okazji nadmienić, że uzyskanie certyfikatu wymaga podpisana stosownej umowy licencyjnej na używanie znaków „Reklamuję etycznie” oraz „Sygnatariusze KER”. Umowa zawierana jest na okres 12 miesięcy z możliwością automatycznego przedłużenia i jest odpłatna. Wysokość tej opłaty uzależniona jest od wydatków reklamowych za rok poprzedni i waha się między 5 a 40 tys. zł rocznie.

\footnotetext{
${ }^{16}$ K. Grzybczyk, Prawo reklamy, dz. cyt., s. 206.

17 Źródło: https://www.radareklamy.pl/pe\%C5\%82na-tre\%C5\%9B\%C4\%87-ker (11.09.2017).

18 A. Karpowicz, Jak reklamować się zgodnie z prawem, dz. cyt., s. 56; źródło: https://www.radareklamy. pl/jak-dziala-samoregulacja (13.09.2017).
} 
Komisja Etyki Reklamy zatem nie ma zbyt dużych możliwości wprowadzenia restrykcji, nawet gdy podmiot jawnie, rażąco i uporczywie narusza postanowienia kodeksu. Nie jest to bowiem akt prawny. Komisja nie ma także możliwości np. wstrzymania emisji reklamy. Może jedynie sugerować zaprzestanie emisji lub dokonanie zmian ${ }^{19}$.

\section{SKuTECZNOŚĆ SAMOREgULACJI}

W przekonaniu autorki Kodeks Etyki Reklamy jest formą zdyscyplinowania środowiska. Pytanie: czy skuteczną? By na to pytanie odpowiedzieć, autorka poniżej przedstawi w formie wykresów dane dostępne na stronie Związku Stowarzyszeń Rady Reklamy z lat 2010-2015 i porówna je ze sobą.

Przedstawione zestawienie w tabeli nr 1 dotyczące liczby skarg pokazuje, że liczba ta jest bardzo zmienna i raczej trudna do porównania. Związek Stowarzyszeń Rada Reklamy tłumaczy to tym, że w poszczególnych latach, gdzie liczba skarg była największa, miała miejsce emisja kontrowersyjnej kampanii, która wzbudziła oburzenie dużej grupy osób.

Tabela 3. Liczba skarg wpływająca w poszczególnych latach do Komisji Etyki Reklamy

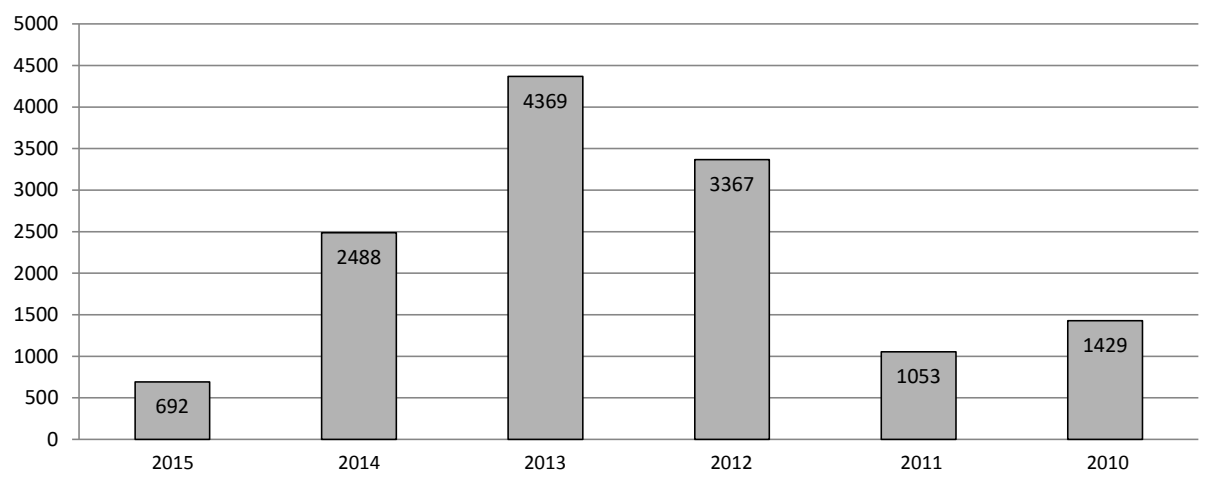

Źródło: https://www.radareklamy.pl/dokumenty, zestawienie własne.

19 Ł. Gaweł, Reklama - wojna o wartości?, w: Wojna w mediach, red. W. Piątkowska-Stepaniak, B. Nierenberg, Opole 2007, s. 164. 
Interesujące jest zestawienie liczby skarg złożonych w poszczególnych latach do Komisji Etyki Reklamy przez konsumentów i przedsiębiorców (zob. tabela nr 4). Wyraźnie widać duże zaangażowanie indywidualnych osób w zgłaszanie naruszeń. Przy tej okazji należy podkreślić, że Związek Stowarzyszeń Rada Reklamy umożliwił konsumentom zgłaszanie zastrzeżeń do wyemitowanych reklam, udostępniając przystępny wzór formularza. Taka forma informowania o naruszeniach jest bezkosztowa, dużo łatwiejsza i szybsza niż wkroczenie na drogę sądową.

Tabela 4. Liczba skarg złożonych w poszczególnych latach do Komisji Etyki Reklamy przez konsumentów i przedsiębiorców

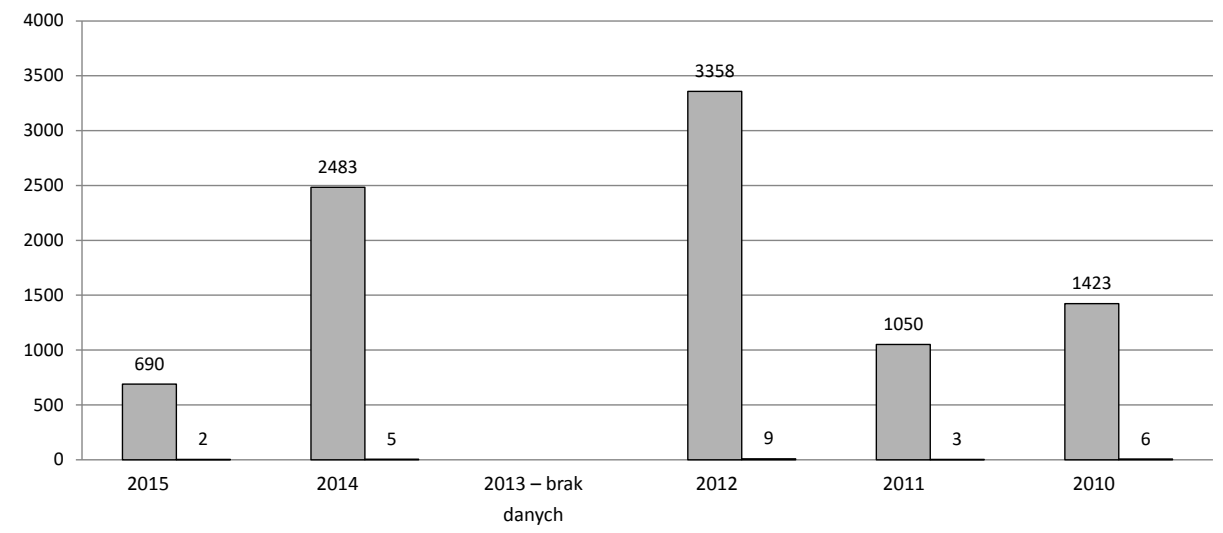

Źródło: https://www.radareklamy.pl/dokumenty, zestawienie własne.

Zastanawiająca jest tak niewielka liczba naruszeń zgłaszanych przez przedsiębiorców. Trudno bowiem uwierzyć, że o działaniach konkurencji nie wiedzą. Z uwagi jednak na ograniczone dane na ten temat autorka nie podejmuje próby odpowiedzi na pytanie, dlaczego przedsiębiorcy nie zgłaszają przypadków nieetycznych zachowań w działalności reklamowej.

Nieco inaczej przedstawiają się wyniki w zakresie liczby postępowań prowadzonych w poszczególnych latach przez Komisję Etyki Reklamy (zob. tabela nr 5). Widać wyraźnie, że od kilku lat liczba występujących i wykrytych w danym roku naruszeń pozostaje na tym samym poziomie. To oznacza, że mimo sformułowanych zasad etycznych działania nieuczciwe w środowisku branży reklamowej od pewnego czasu się nie zmniejszają. 
Tabela 5. Liczba postępowań prowadzonych w poszczególnych latach przez Komisję Etyki Reklamy

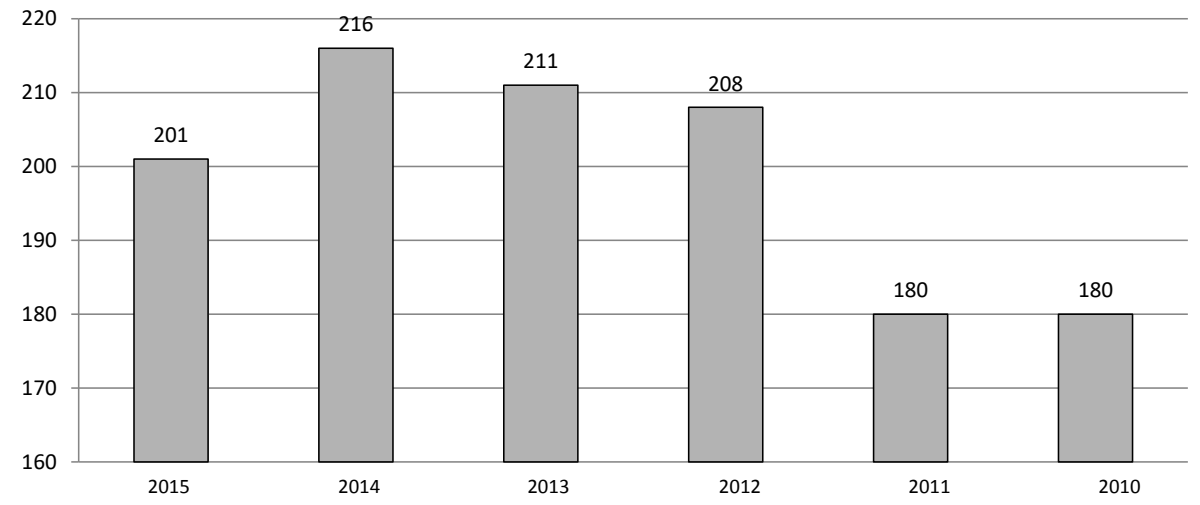

Źródło: https://www.radareklamy.pl/dokumenty, zestawienie własne.

Na zakończenie autorka zestawiła liczbę złożonych skarg z liczbą zarzutów, z którymi częściowo lub całkowicie zgodziła się Komisja Etyki Reklamy (zob. tabela nr 6). Zauważalne jest, że komisja ze złożonymi skargami w dużej mierze się zgadza, co oznaczałoby, że zasady sformułowane w kodeksie są zrozumiałe nie tylko przez środowisko branżowe, ale także przez samych konsumentów.

Tabela 6. Liczba zarzutów, z którymi częściowo lub całkowicie zgodziła się Komisja Etyki Reklamy, w stosunku do wszystkich złożonych skarg

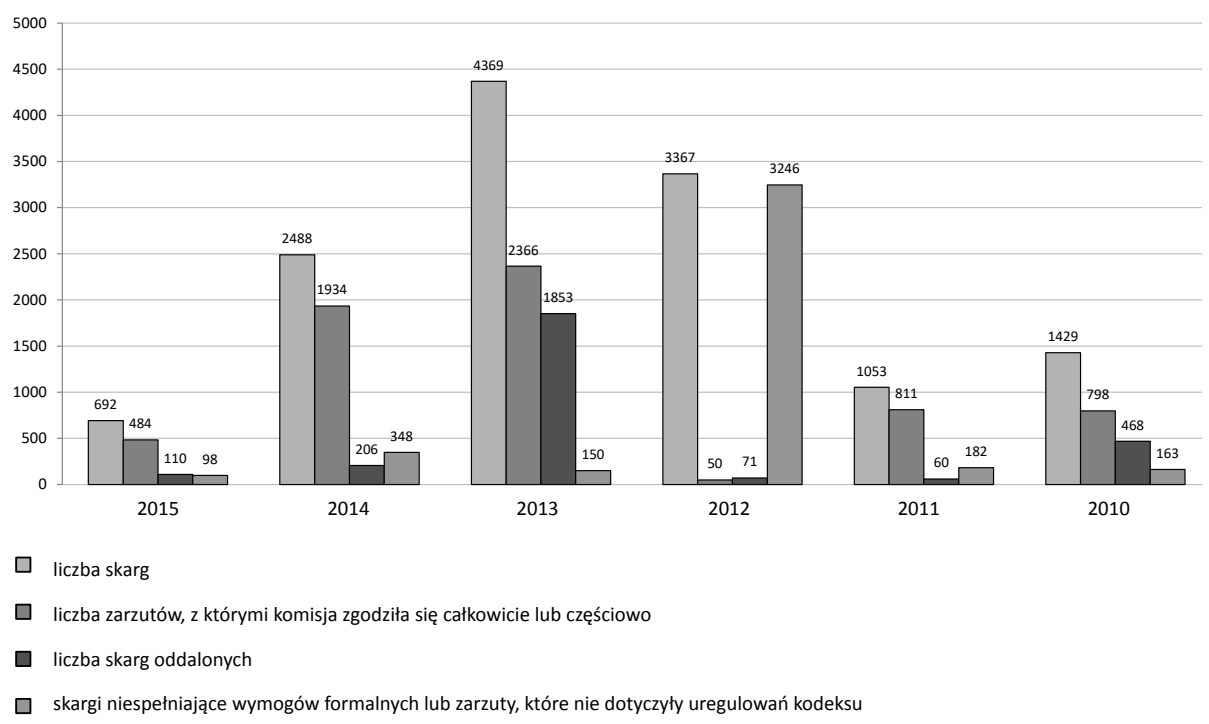

Źródło: https://www.radareklamy.pl/dokumenty, zestawienie własne. 


\section{WNIOSKI}

Wydaje się, że normy zawarte w Kodeksie Etyki Reklamy ułatwiają interpretację przepisów prawa. Uszczegółowienie i liczne przykłady sprawiają, że normy uwzględnione w kodeksie są czytelne i łatwiej je zastosować w praktyce.

Zdecydowanie największą zaletą stosowania norm etycznych jest uzyskanie statusu firmy reklamującej etycznie. Zatem wartość wizerunkowa jest pierwszorzędna. Komisja Etyki Reklamy nie ma wielkich możliwości wprowadzania restrykcji, co stanowi wadę samoregulacji. Ale, jak słusznie zauważa Andrzej Karpowicz, „istnienie kodeksów etyki skutecznie pozbawia jakiegokolwiek alibi przedsiębiorców nieuczciwych (umyślnie i nieumyślnie). Nie sposób już tłumaczyć swojego nieuczciwego postępowania wyjaśnieniem: «przecież nie ma w tym nic złego, wszyscy tak robią» itp. - kwalifikacja moralna takiego postępowania jest już bowiem oczywista, a ostracyzm całego uczciwego środowiska powinien izolować nieuczciwych"20.

W tym miejscu przechodzimy do sedna, czy posądzenie przez środowisko branżowe o działania nieetyczne i ryzyko utraty zaufania konsumentów powstrzymuje reklamodawców przed emitowaniem reklam nieuczciwych? Przytoczone statystyki dotyczące liczby złożonych w poszczególnych latach skarg i postępowań w zakresie działań nieetycznych w dziedzinie reklamy nie napawają zbytnim optymizmem. Czy zatem należałoby się zgodzić ze spostrzeżeniem Łukasza Gawła, który pisał: „pytanie o wartości w reklamie można uznać za niestosowne. W końcu reklama jest po to - używając tautologii - by reklamować. Sięgając po określenia bardziej precyzyjne: komunikat reklamowy służy skłanianiu odbiorcy do sięgnięcia po określony produkt bądź usługę. Gdzie tu miejsce na wartości?"21.

\section{LITERATURA}

Ciechanowska J., Etyczne granice reklamy politycznej, „Zeszyty Naukowe Uniwersytetu Rzeszowskiego" 77 (2013), s. 23-34.

Gaweł Ł., Reklama - wojna o wartości?, w: Wojna w mediach, red. W. Piątkowska-Stepaniak, B. Nierenberg, Opole 2007, s. 159-164.

Grochowski R., Granice prawne i etyczne reklamy w ustawodawstwie krajowym i europejskim, Poznań-Opole 2010.

Grzybczyk K., Prawo reklamy, Warszawa 2008.

https://www.radareklamy.pl/jak-dziala-samoregulacja (13.09.2017).

https://www.radareklamy.pl/kodeks-etyki-reklamy?showall=\&start=2 (8.09.2017).

https://www.radareklamy.pl/pe\%C5\%82na-tre\%C5\%9B\%C4\%87-ke (11.09.2017).

Janiszewska K. i in., Wiedza o reklamie. Od pomysłu do efektu, Bielsko-Biała 2010.

20 A. Karpowicz, Jak reklamować się zgodnie z prawem, dz. cyt., s. 56.

21 Ł. Gaweł, Reklama - wojna o wartości?, dz. cyt., s. 159. 
Karpowicz A., Jak reklamować się zgodnie z prawem, Warszawa 1997.

Murawska-Najmiec E., Informacje na temat istniejacych $w$ Polsce zasad etycznych $w$ dziedzinie wplywających na zawartość mediów, „Analiza Biura KRRiT” (2006) nr 8, s. 1-72.

Nowacki R., Podręcznik. Reklama, Warszawa 2006.

Pluszyńska A., Prawo reklamy, w: Zarządzanie reklama, red. B. Nierenberg, Kraków 2015, s. $57-80$.

Słownik wspótczesnego słownika polskiego, red. B. Dunaj, Warszawa 1996.

Ustawa z dnia 16 kwietnia 1993 r. o zwalczaniu nieuczciwej konkurencji, Dz.U. 1993 Nr 47 poz. $211 \mathrm{ze} \mathrm{zm}$.

Ustawa z dnia 19 listopada 2009 r. o grach hazardowych, Dz.U. 2009 Nr 201 poz. 1540 ze zm.

Ustawa z dnia 23 sierpnia 2007 r. o przeciwdziałaniu nieuczciwym praktykom rynkowym, Dz.U. 2007 Nr 171 poz. 1206 ze zm.

Ustawa z dnia 26 lipca 2005 r. o przeciwdziałaniu narkomanii, Dz.U. 2005 Nr 179 poz. 1485 ze zm.

Ustawa z dnia 26 października 1982 r. o wychowaniu w trzeźwości i przeciwdziałaniu alkoholizmowi, Dz.U. 1982 Nr 35 poz. 230 ze zm.

Ustawa z dnia 26 stycznia 1984 r. - Prawo prasowe, Dz.U. 1984 Nr 5 poz. 24 ze zm.

Ustawa z dnia 27 kwietnia 2001 r. - Prawo ochrony środowiska, Dz.U. 2001 Nr 62 poz. 627 ze zm.

Ustawa z dnia 29 grudnia 1992 r. o radiofonii i telewizji, Dz.U. $1992 \mathrm{Nr} 7$ poz. 34 ze zm.

Ustawa z dnia 30 czerwca 2000 r. Prawo własności przemysłowej, Dz.U. 2001 Nr 49 poz. 508 ze zm.

Ustawa z dnia 4 lutego 1994 r. o prawie autorskim i prawach pokrewnych, Dz.U. $1994 \mathrm{Nr} 24$ poz. 83 ze zm.

Ustawa z dnia 6 września 2001 r. Prawo farmaceutyczne, Dz.U. 2001 Nr 126 poz. 1381 ze zm.

Ustawa z dnia 9 listopada 1995 r. o ochronie zdrowia przed następstwami używania tytoniu i wyrobów tytoniowych, Dz.U. $1996 \mathrm{Nr} 10$ poz. 55 ze zm. 